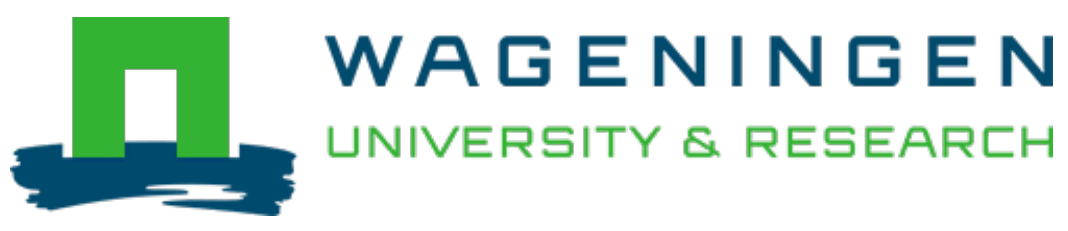

\title{
New pathways and the associated uncertainties for increasing maize water use efficiency under global warming
}

\author{
Archives of Agronomy and Soil Science \\ Kalanaki, M.; Karandish, Fatemeh; Ritzema, H.P.; Kalanaki, Moosa \\ https://doi.org/10.1080/03650340.2020.1864340
}

This article is made publicly available in the institutional repository of Wageningen University and Research, under the terms of article $25 \mathrm{fa}$ of the Dutch Copyright Act, also known as the Amendment Taverne. This has been done with explicit consent by the author.

Article 25 fa states that the author of a short scientific work funded either wholly or partially by Dutch public funds is entitled to make that work publicly available for no consideration following a reasonable period of time after the work was first published, provided that clear reference is made to the source of the first publication of the work.

This publication is distributed under The Association of Universities in the Netherlands (VSNU) 'Article $25 \mathrm{fa}$ implementation' project. In this project research outputs of researchers employed by Dutch Universities that comply with the legal requirements of Article $25 \mathrm{fa}$ of the Dutch Copyright Act are distributed online and free of cost or other barriers in institutional repositories. Research outputs are distributed six months after their first online publication in the original published version and with proper attribution to the source of the original publication.

You are permitted to download and use the publication for personal purposes. All rights remain with the author(s) and / or copyright owner(s) of this work. Any use of the publication or parts of it other than authorised under article $25 \mathrm{fa}$ of the Dutch Copyright act is prohibited. Wageningen University \& Research and the author(s) of this publication shall not be held responsible or liable for any damages resulting from your (re)use of this publication.

For questions regarding the public availability of this article please contact openscience.library@,wur.nl 


\section{New pathways and the associated uncertainties for increasing maize water use efficiency under global warming}

\section{Mahdi Kalanaki , Fatemeh Karandish , Henk Ritzema \& Moosa Kalanaki}

To cite this article: Mahdi Kalanaki , Fatemeh Karandish , Henk Ritzema \& Moosa Kalanaki (2020): New pathways and the associated uncertainties for increasing maize water use efficiency under global warming, Archives of Agronomy and Soil Science, DOI: $10.1080 / 03650340.2020 .1864340$

To link to this article: https://doi.org/10.1080/03650340.2020.1864340

Published online: 28 Dec 2020.

Submit your article to this journal $\square$

Џ Article views: 38

a

View related articles

View Crossmark data \lceil 


\title{
New pathways and the associated uncertainties for increasing maize water use efficiency under global warming
}

\author{
Mahdi Kalanaki $\mathbb{D}^{\mathrm{a}, \mathrm{b}}$, Fatemeh Karandish ${ }^{\mathrm{a}, \mathrm{c}}$, Henk Ritzema $\mathbb{D}^{\mathrm{b}}$ and Moosa Kalanaki $\mathbb{D}^{\mathrm{d}}$ \\ aWater Engineering Department, University of Zabol, Zabol, Iran; ${ }^{b}$ Water Resource Management Group, \\ Wageningen University and Research, Wageningen, The Netherlands; 'Twente Water Centre, University of Twente, \\ Enschede, The Netherlands; 'Software Engineering Department,Tejarat Iranian Digital Development (Tiddev) Co., \\ Tehran, Iran
}

\begin{abstract}
The DSSAT4.7-CERES model was employed to simulate plant-water nexus conditions in the future of Mazandaran province in Iran, using ensemble outputs of various GCMs and emission scenarios with LARSWG 5.5 in the time period 2010-2100. The results showed during the $21^{\text {st }}$ century, maize water requirement is expected to be reduced by 3.3-14.1\%. Under climate change scenarios, both negative and positive changes in crop yield are projected, between -37.4 and $36.1 \%$, which consequently results in a $5.1-27.2 \%$ reduction in water use efficiency (WUE) in the future periods. Deficit irrigation (DI) with $25 \%$ reduction in irrigation water depth $\left(\mathrm{Dl}_{75}\right)$ lead to a moderate reduction of $4.3-5.5 \%$ in WUE, but WUE was highly reduced under $\mathrm{DI}_{55}$. While early planting may reduce WUEs by $0.4-17 \%$, late planting almost resulted in improved WUE, especially under $\mathrm{DI}_{75}$. Less frequent irrigation significantly reduces actual evapotranspiration, which consequently resulted in improved WUE by $0.57-42.47 \%$. In conclusion, the integrated assessment reveals that $\mathrm{DI}_{75}$, with an irrigation interval of 5 days, together with a 20 days delay in cropping date of maize in Mazandaran province, may be considered as an effective adaptation solution, when considering both food and water security.
\end{abstract}

\section{ARTICLE HISTORY}

Received 8 March 2020

Accepted 11 December 2020

\section{KEYWORDS}

Planting date; irrigation intervals; deficit irrigation; DSSAT; maize

\section{Introduction}

Rapid population growth and changes in diets has caused a significant increase in food demand and consequently, fresh water requirement for food production over the past years (Kang et al. 2017; Muluneh et al. 2017). Additionally, food security may be further threatened under conditions of global warming due to alterations to regional water cycles (Karandish and Hoekstra 2017; Karandish et al. 2017a; FAO 2018). On one hand, climate change is reported to result in lower water availability worldwide (Rad et al. 2015; Jepsen et al. 2018; Wang et al. 2018). On the other hand, the amount of water required by cereals, as the dominant crops in many regions of the world, is expected to be increased under elevated $\mathrm{CO}_{2}$ during the $21^{\text {th }}$ century (Karandish et al. 2017a; Wang et al. 2018). Hence, water consumption management within agricultural lands may be considered as a promising way to achieve food security under global warming (Saseendran et al. 2015), with positive implications for water security since agriculture is the largest contributor to the total freshwater consumption (FAO 2018). 
Various water-saving irrigation strategies have been established to reduce water consumption through the crop production process. Deficit irrigation (DI), among various water-saving irrigation strategies, has been reported to be a rational solution under water scarcity (Ma et al. 2017; da Silva et al. 2017; Kalanaki et al. 2020). Paredes et al. (2014) indicated that a mild water deficit for maize with AquaCrop model had a greater water productivity (WP). Moreover, positive consequences of regulated DI, where water stress is exposed during less sensitive growth stages, has been demonstrated in some studies (Talebnejad and Sepaskhah 2014; Kang et al. 2017). Hence, achieving a favorable level of water-use efficiency under DI requires integrating efficient field management practices into such water-saving irrigation strategy to prevent yield reduction under water stress.

While the consequences of adopting water management strategies within agricultural lands could be evaluated under field investigations, such experiments are always laborious and timeconsuming, and therefore expensive (Jiang et al. 2016; Ma et al. 2017). Therefore, combination of field experiments with crop models are necessary to achieve appropriate results (Saseendran et al. 2015; Attia et al. 2016). Modeling could be a suitable alternative tool under such conditions which helps with identifying optimal scenarios, particularly when field investigations are unfeasible due to economic or technical limits (Karandish and Šimůnek 2017; Hoogenboom et al. 2019). Some of different available models include, SUCROS (van Laar et al. 1997), WOFOST (van Diepen et al. 1989), CropSyst (Stockle et al. 1994), APSIM (McCown et al. 1996), Epic (Williams et al. 1989), and STICS (Brisson et al. 2003). The DSSAT model is known as a comprehensive widely used model for simulating soil-crop-water relations (Hoogenboom et al. 2019). Analyzing crop responses to the selected planting date (Soler et al. 2007; Lana et al. 2016; Ding et al. 2016; Jiang et al. 2016), irrigation scheduling (Attia et al. 2016; Jiang et al. 2016; da Silva et al. 2017), fertilizer application management (Jeong et al. 2014) and climate change and climate variability (Lin et al. 2008; Johnston et al. 2015; Ma et al. 2017) are applications in which DSSAT has been successfully used.

Previous studies have predominantly focused on quantifying probable consequences of reducing irrigation water volume applied over the cropping cycles under various water-saving irrigation strategies (Romero-Trigueros et al. 2017; Yang et al. 2017; Ma et al. 2017). The 10-26 days backward in planting date under global warming in Mazandaran province showed a possible solution for decreasing the crop water requirement of maize (Karandish et al. 2017a). Earlier planting dates (near 110 Julian days number) could increase water productivity in rice cultivation and more usage of green water in Mazandaran province (Darzi-Naftchali and Karandish 2019). The rice water requirement in this province predicted a decreasing trend during 2016-2045 under the A2 scenario (Gilanipour and Gholizadeh 2016). In addition, the possible effects of climate change on the surface water quality (Nosrati 2011), runoff reduction (Karimi et al. 2018), increase in temperature and decrease in precipitation (Rahimi et al. 2019) have been reported for Mazandaran province that could affect on water requirement and agricultural section in this area. Other studies in different regions indicate that the level of imposed water stress highly affects crop yield and water consumption. The large diversity in the reported results for different regions demonstrates the substantial influence of climate variability on the prospected consequence (Bastiaanssen and Steduto 2017). However, the probable effects of adopting water-saving irrigation strategies under climate change has rarely been investigated (Yang et al. 2017; Ma et al. 2017; Fraga et al. 2018). On the other hand, integrating other field management practices into such water-saving methods may be of consideration when deciding to implement new targets for lowering down agricultural water consumption under global warming.

In this research, we utilized a comprehensive field-modeling approach to identify promising solutions for promoting water productivity with maize crop under current and future climates. Our main objectives include (i) calibrating and validating the DSSAT4.7-CERES-Maize model to properly simulate the interactions between soil, water, and crop, by using related data collected during two cropping cycles in Sari region. (ii) Projecting a wide range of possible change in weather data under global warming on crop yield, water requirement, and WUE. (iii) Finally, explore promising scenarios for achieving sustainable maize production under climate change. 


\section{Materials and methods}

\section{Field investigation}

During 2010 and 2011, the field investigation was conducted in a maize field equipped with a drip irrigation system in Sari Agricultural Sciences and Natural Resources University (SANRU), Sari, Iran. Based on the long-term daily recorded weather data, this region has an average minimum and maximum air temperature of $-6^{\circ} \mathrm{C}$ and $38.9^{\circ} \mathrm{C}$, respectively, and receives a total of $616 \mathrm{~mm}$ of rainfall. The study area is classified as a Hyper-humid region (Karandish et al. 2017a). Soil texture was sandyclay-loam for 0-0.2 m, and clay-loam for 0.2-1 m soil depth (Karandish and Šimůnek 2017).

The field experiment consists of three treatments: Fl treatment (crops are fully irrigated), and two DI treatments [deficit irrigation at deficit 55\% $\left(\mathrm{Dl}_{55}\right)$ and $75 \%\left(\mathrm{Dl}_{75}\right)$ ]. The experiment was conducted in a complete block design. Before crop cultivation, the field was facilitated with drip-irrigation systems. The space in between drip lines were $0.75 \mathrm{~m}$. Inline emitters were $0.2 \mathrm{~m}$ apart in drip lines, and emitters discharge was $2 \mathrm{~L} \mathrm{~h}^{-1}$.

Crops were sown on May 26, 2010 and 2011, with crop row of 0.75 m, and crop spacing of $0.2 \mathrm{~m}$. During both cropping cycles, irrigation was carried out every other day. When irrigating crops in the Fl treatment, soil water content in the root-zone was backed to field capacity during irrigation, as described in Equation 1: (Karandish and Šimůnek 2017):

$$
\left[I_{n}\right]_{F I}=\sum_{i=1}^{m}\left\{\left[\theta_{F C i}-\left(\theta_{B l i}\right)_{F I}\right] D_{i}\right\}
$$

Where, $\left[I_{n}\right]_{F I}$ is the net irrigation water depth $(\mathrm{mm})$ for of the $\mathrm{nth}$ irrigation event in the FI treatment, $\theta_{F C i}$ is the soil water content at field capacity $(\mathrm{FC}, \%)$ for the ith soil layer, $\left(\theta_{\mathrm{Bli}}\right)_{\mathrm{Fl}}$ is the average soil water content for the ith soil layer (\%) before irrigation in the FI treatment, $D_{i}$ is the thickness of soil layer $(50 \mathrm{~mm}), i$ is the number of soil layer, and $m$ shows the whole number of soil layers down to a specific soil depth $(m=16)$, for which $\left[I_{n}\right]_{F I}$ is calculated.

During 1-55 days after sowing (DAS) in 2010, and 1-45 DAS in 2011, the irrigation water depth was the same for all treatments. Thereafter and until the end of the growing seasons, the $\mathrm{DI}_{55}$ and $\mathrm{Dl}_{75}$, respectively, received only $55 \%$ and $75 \%$ of the full irrigation water.

The harvest time was 107 DAS in 2010, and 110 DAS in 2011. In these dates, all crop parameters considered above, and crop yield were determined. Additional details on field trial could be found in (Karandish and Šimůnek 2017).

\section{Modeling approach}

Maize-growing process could be simulated with the DSSAT CERES-maize model version 4.7 (Hoogenboom et al. 2019). The model input data include weather data, soil characteristics, crop properties, and field management practices, all of which were entered accordingly in DSSAT specific files. The model calibration was handled by using field data obtained in 2010. During the calibration process, six crop parameters, as described in Table 2, were adjusted until achieving a satisfactory agreement between the simulated and observed data. The calibrated parameters, for which the simulation error for predicting maximum Leaf area index, tops weight at maturity, grain yield, anthesis day, and physiological maturity day falls within the goodness of fit (see the section; criteria indices) were then validated based on field data collected during 2011 growing season. The model was then used to analyze the possible consequences of the defined management scenarios.

\section{Scenario assessment}

After analyzing the reliability of the DSSAT model, the model was applied to assess further consequences of various management scenarios. Hence, we first considered two-time period: the base time period (BTP) and the future time period (FTP). BTP is considered over the years 1980-2010. FTP 
were divided into three periods: early $21^{\text {th }}$ century (2011-2040, FTP 1 ), mid-2 ${ }^{\text {th }}$ century (2041-2070, $\mathrm{FTP}_{2}$ ), and late $21^{\text {th }}$ century (2071-2100, $\left.\mathrm{FTP}_{3}\right)$. For BTP, climatic data on a daily time-scale were collected form the synoptic station located within the study area from Iran's Meteorological Organization. The 15 general circulation models (GCMs) introduced in IPCC-AR4 were adopted to obtain climate projections for FTPs (see GCMs reported in Karandish et al. 2017b). This wide range of models were considered the probable uncertainties when reporting the simulated results for the FTPs. Besides, all these model outputs were downscaled under B1, A1B and A2 emission scenarios, respectively, representing low, medium, and high levels of greenhouse gases emissions. Based on IPCC (2007), the qualitative results derived from A1B, A2, and B1 are more probable compared to the other SRES scenarios. Downscaling the weather data for the future periods was completed using the LARS-WG 5.5 which is a stochastic weather generator (Semenov and Barrow 2002).

The weather data for BTP and those downscaled for FTPs were then used to quantitatively analyze the further consequences of defined management scenarios regarding the relations between soil, water, and crop by using the DSSAT-CERES-Maize model. For each time period (i.e., BTP or FTPs), a wide range of various scenario were defined by different irrigation management scenarios (IMS) and field management scenarios (FMS). IMS include the amount of applied irrigation water depth (IL) and irrigation intervals. Same as the BTP, IL was considered to be $100 \%$ (where crop water demand is fully supplied in each irrigation events), $75 \%$ (in which only $75 \%$ of crop water requirement is supplied), and $55 \%$ (in which only $55 \%$ of crop water requirement is supplied). We also considered five irrigation intervals: every 1, 2, 3, 4, or 5 days. FMS include different cropping calendars, since the time of crop cultivation is reported to be highly influenced by global warming (Kassie et al. 2015; Muluneh et al. 2017). Based on the three parameters, including crop yield, consumed water by crop (i.e., actual ET), and WUE (water use efficiency $\left.=\frac{\text { yield }}{\text { actualET }}\right)$, the best scenario for achieving sustainable maize cultivation within the study area was then determined for both current and future periods.

\section{Criteria indices}

The performance of the selected models, including the LARS-WG and the DSSAT models, were then evaluated based on normalized root mean square error (nRMSE), index of agreement (d), and coefficient of determination $\left(R^{2}\right)$ indices (Soler et al. 2007; Jeong et al. 2014; Chisanga et al. 2015).

$$
\begin{gathered}
n R M S E=\sqrt{\frac{1}{n} \sum_{i=1}^{n}\left(Y_{i}-X_{i}\right)^{2}} \times \frac{100}{\bar{X}} \\
R^{2}=\frac{\left[\sum_{i=1}^{n}\left(X_{i}-\bar{X}\right)\left(Y_{i}-\bar{Y}\right)\right]^{2}}{\sum_{i=1}^{n}(X-\bar{X})^{2} \sum_{i=1}^{n}(Y-\bar{Y})^{2}} \\
d=1-\left[\frac{\sum_{i=1}^{n}\left(Y_{i}-X_{i}\right)^{2}}{\sum_{i=1}^{n}\left(\left|Y_{i}-\bar{X}\right|+\left|X_{i}-\bar{X}\right|\right)^{2}}\right]
\end{gathered}
$$

Where $Y_{i}$ and $X_{i}$ refer to the simulated and field-observed data, respectively, $\bar{Y}$ and $\bar{X}$, are, respectively, the average of the model-simulated and field-observed data, and $n$ is the number of the considered data. The lower nRMSE (i.e., lower than 10\%) confirms higher accuracy. $R^{2}$ and $d$ vary between 0 and $1 . R^{2}=1$ (or $d=1$ ) is an indication of more accurate estimation (Soler et al. 2007) 


\section{Results and discussion}

\section{Model efficiency}

\section{Efficiency of LARS-WG}

The observed weather data, together with those simulated by the LARS model during the base period (i.e., 1980-2010), has been shown in supplemental information where the coefficients of variation for the observed and simulated data are also presented. These information indicate that the model was capable of capturing the temporal trends in weather data (i.e., including rainfall, minimum and maximum temperatures, defined as Tmin and Tmax, respectively), a better estimation was observed for air temperature. A bias of $0.63-4.17 \mathrm{~mm}$ in rainfall, $0.31-0.58{ }^{\circ} \mathrm{C}$ in Tmin, and $0.45-0.75^{\circ} \mathrm{C}$ in $\mathrm{Tmax}$ is obtained when comparing the observed monthly weather data with those simulated by the LARS-WG. A better estimation of air temperature is also reported by some other researchers (Reddy et al. 2014; Karandish et al. 2017b).

\section{Efficiency of DSSAT-CERES-maize}

The calibrated phenological data, reported in Table 1, which are given based on field data collected in 2011 growing season, are similar to those obtained in other investigations for the same maize cultivar (Soler et al. 2007; Musinguzi et al. 2014; Chisanga et al. 2015).

Applying these coefficients results in satisfactory agreement results when simulating maize growth, as is presented in Table 2. While the nRMSE was lower than $10 \%$ for all selected properties, which is an indication of model capability for simulating soil-water-crop relations (Soler et al. 2007). The model was the most accurate when simulating the day of anthesis and maturity, and was the less accurate when simulating crop aboveground weight. The calibrated model was then validated based on data collected over 2010 growing seasons. Results given in Table 2 show that the model is reliable for scenario analysis since all criteria indices falls within the acceptable values (nRMSE $=1.09-9.59 \%$, $\mathrm{d}=0.81-1)$.

Table 1. The calibrated phonology crop coefficients of maize single-cross hybrid-704 based on field-data collected over a 2-year field research in the study area.

\begin{tabular}{lcccccc}
\hline Coefficients & P1 & P2 & P5 & G2 & G3 & PHINT \\
\hline Parameters values & 196.1 & 0.549 & 727.5 & 476.9 & 14.25 & 58.75 \\
*P1: The cumulative degree days from the emergence to end of juvenile phase, P2: the photoperiod sensitivity coefficient, P5: \\
the cumulative degree days from the silking stage till the physiological maturity, G2: potential kernel number, G3: potential \\
kernel growth rate (mg kernel ${ }^{-1} \mathrm{~d}^{-1}$ ), \\
interval) $\left({ }^{\circ} \mathrm{CH}\right.$ d)
\end{tabular}

Table 2. Statistical comparison between the observed and the simulated crop properties over the calibrated (the 2010 growing season) and the validated (the 2011 growing season) periods.

\begin{tabular}{|c|c|c|c|c|c|c|c|c|c|c|c|}
\hline \multirow[b]{2}{*}{ Period } & \multirow[b]{2}{*}{ Parameters* } & \multicolumn{3}{|c|}{ Measured values } & \multicolumn{3}{|c|}{ Simulated values } & \multicolumn{4}{|c|}{ Criteria analysis ${ }^{* *}$} \\
\hline & & $\mathrm{FI}$ & $\mathrm{Dl}_{75}$ & $\mathrm{Dl}_{55}$ & $\mathrm{FI}$ & $\mathrm{Dl}_{75}$ & $\mathrm{Dl}_{55}$ & RMSE & NRMSE (\%) & $\mathrm{R}^{2}$ & d \\
\hline \multirow[t]{5}{*}{ Calibration period } & LAIX & 3.70 & 3.00 & 2.80 & 3.60 & 3.30 & 3.00 & 0.22 & 6.80 & 0.91 & 0.90 \\
\hline & TW $\left(\mathrm{t} \mathrm{ha}^{-1}\right)$ & 16.00 & 14.50 & 13.20 & 14.90 & 13.00 & 12.40 & 1.20 & 8.00 & 0.94 & 1.00 \\
\hline & Yield $\left(\mathrm{t} \mathrm{ha} \mathrm{a}^{-1}\right)$ & 6.60 & 5.30 & 4.90 & 6.74 & 5.42 & 5.02 & 0.13 & 2.28 & 1.00 & 1.00 \\
\hline & An. D & 57 & 57 & 57 & 57 & 57 & 57 & 0.00 & 0.00 & - & 1.00 \\
\hline & M. D & 95 & 95 & 95 & 95 & 95 & 95 & 0.00 & 0.00 & - & 1.00 \\
\hline \multirow[t]{5}{*}{ Validated period } & LAIX & 4.30 & 3.60 & 3.30 & 4.20 & 3.90 & 3.70 & 0.29 & 7.89 & 0.81 & 0.92 \\
\hline & TW (t ha $\left.{ }^{-1}\right)$ & 17.00 & 14.50 & 13.20 & 14.90 & 13.02 & 12.40 & 1.16 & 8.00 & 1.00 & 0.94 \\
\hline & Yield $\left(\mathrm{t} \mathrm{ha}^{-1}\right)$ & 7.00 & 5.50 & 4.20 & 6.95 & 5.98 & 4.34 & 0.54 & 9.59 & 1.00 & 0.86 \\
\hline & An. D & 54 & 54 & 54 & 55 & 55 & 55 & 1 & 1.85 & - & 1 \\
\hline & M. D & 92 & 92 & 92 & 93 & 93 & 93 & 1 & 1.1 & - & 1 \\
\hline
\end{tabular}

* LAIX: maximum leaf area index (dimension less), TW: tops weight at maturity, Yield: maize grain yield, An.D: the date of anthesis, M.D: the day of physiological maturity

** RMSE: root mean square error, nRMSE: normalized root mean square error, $d$ : index of agreement, $R^{2}$ : regression coefficient 


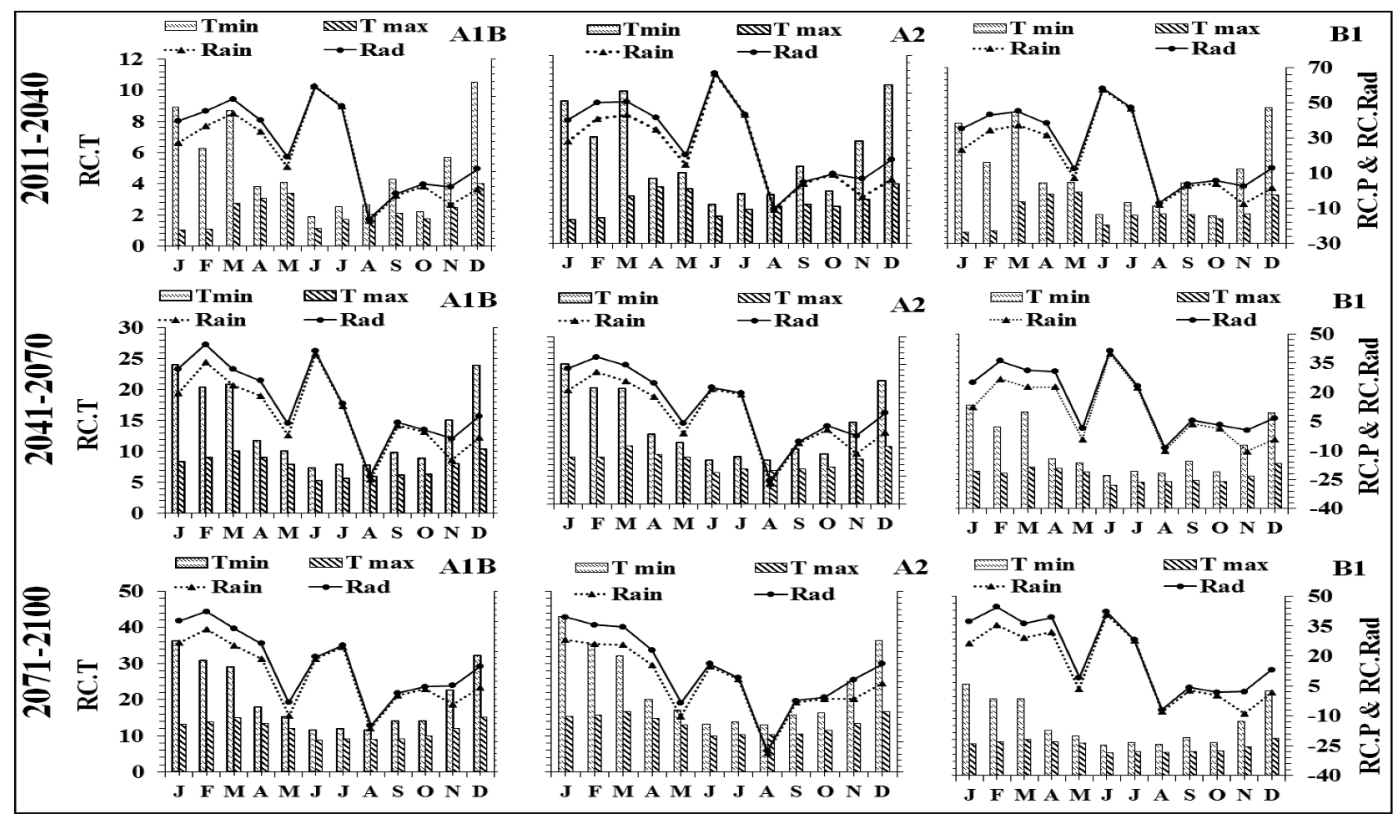

Figure 1. Projected relative climate changes for weather data based on the average results of the $15 \mathrm{GCMs}$ for each scenario in the future periods. i.e., Rc.T, RC.Rad and RC.P denotes the relative change in air temperature, radiation and precipitation, respectively.

\section{Projections of climate change}

\section{Climatic variable}

Figure 1 shows the projection of weather data, including monthly precipitation, Tmin, and Tmax. While climate change projections lead to an increase in weather data, a non-uniform increase was observed among GCMs and SRES scenarios. The highest change in both air temperature and precipitation almost happen under A2 scenario, while B1 scenario almost projects the lowest change in the considered weather data.

Compared to the BTP, global warming projects an increase in the monthly mean air temperature under all emission scenarios, with a range of $1.88-43.08 \%$ for Tmin, and a range of $0.79-16.78 \%$ for Tmax. Similarly, previous research has indicated a warmer climate for Iran over the future periods (Rad et al. 2015; Karandish et al. 2017b). Nevertheless, our results demonstrated that these projections were not uniform for all months. Wet seasons are exposed to higher increase in air temperature, particularly during the late $21^{\text {th }}$ century (i.e., 2071-2100).

Regardless of the SRES scenarios or time period, climate change shows a considerable change in monthly precipitation, projected by $-30.6 \%$ (under A2 scenario, and for August over the 2071-2100 period), to $60.4 \%$ (under A2, and for June over the 2011-2040 period). Precipitation increase is of priority since such an increase over the wet seasons results in water-logging problems, and results in significant yield loss over the dry season, caused by weeds and pests growth, and an increase in soil erosion (Karandish et al. 2017a). caused by considerable change in the available water in soil (Wang et al. 2018).

\section{Crop water requirement}

While being projected to a $14.1-3.27 \%$ decrease under global warming, crop water requirement is expected to have lower change under B1 over the early $21^{\text {th }}$ century, and it is projected to the highest variation under $A 2$ over the late $21^{\text {th }}$ century (Table 3). Although a linear relationship has been reported between ETc and air temperature (Allen et al. 1998). Reduced ETc may be justified by 


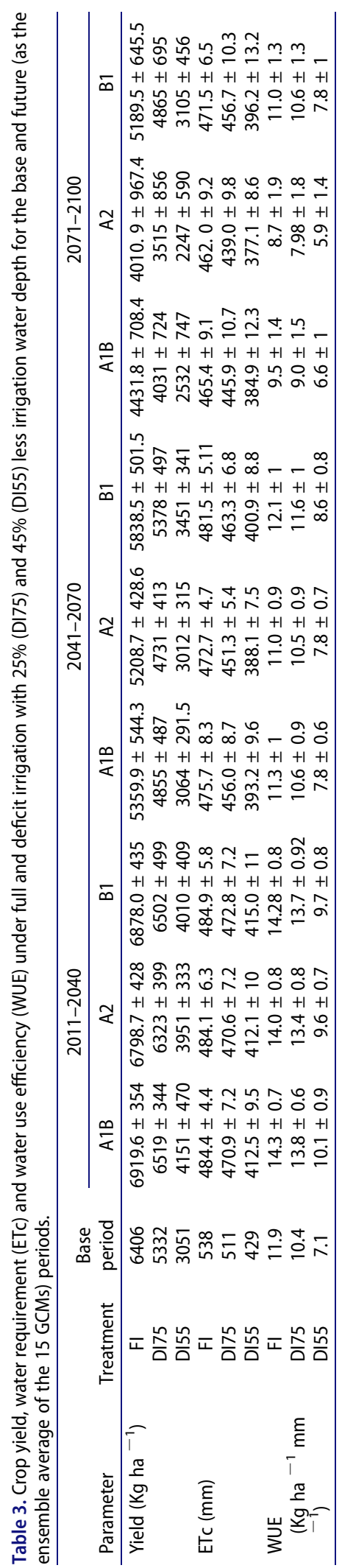


this logic that reduced length of cropping cycles may compensate for the negative effects of elevated temperature or limited soil water storage under future climate. Our results are in agreements with the finding of those reported in the other related studies (Atlin et al. 2017; Wang et al. 2017; Lizaso et al. 2018).

\section{Crop yield}

Over the period 2011-2100, climate change may cause either negative or positive change in maize yield in the range of -37.4 to $36.1 \%$, compared to the BTP, with the lowest and the highest thresholds under A1B, (36.1\% the most optimistic scenario) and A2 ( $-37.4 \%$, the most pessimistic scenario) SRES scenarios, respectively (Table 3 ). Yield reduction may be inconsistent with the elevated air temperature since previous research have reported a significant relationship between maize grain yield and air temperature due to reduced growth duration (Lizaso et al. 2018). Yield reduction under projected climate change in some cases has also been reported by other researchers (Karandish et al. 2017b; Huang et al. 2018). Regardless of the type of the SRES scenarios, the highest reduction in maize grain yield may occur across the late $21^{\text {th }}$ century (i.e., over the period 2071-2100). This result may be attributed to the higher air temperature increase over the period 2071-2100, compared to those over the period 2011-2070. Other researchers also reported a higher risk of economic loss through greater yield reduction over the late $21^{\text {th }}$ century (Muluneh et al. 2017; Ma et al. 2017).

\section{Crop water use efficiency}

While global warming projected a considerable increase in WUE over the period 2011-2040, a general reduction of 5.1-27.2\% in WUE was observed over the period 2041-2100, with the lowest and the highest thresholds under A1B over the period 2041-2070 (5.1\%), and under A2 over the 2071-2100, respectively (Table 3). Despite a considerable reduction in ETc over the mid and the late $21^{\text {th }}$ century, reduced WUE may be attributed to higher yield reduction under climate change (Huang et al. 2018). The combination of canopy warming and $\mathrm{CO}_{2}$ enhancement had reducing effects of around $3.5-18.2 \%$ on grain maize yield (Wang et al. 2018). Climate change reduced $23 \%$ of water productivity on maize (Yang et al. 2017). On the other hand, WUE for maize during 2071-2090 could be increased under full and deficit irrigation around $12.8 \%$ and $12.1 \%$, respectively (Ma et al. 2017). The WUE under global warming could improve in the semi-arid regions of China (Guoju et al. 2013). These different results show that WUE response to climate changes is highly related to conditions of the study region, level of increased temperature, crop cultivars and the interactions with different parameters (Hatfield and Dold 2019). However, the reduction trends of WUE may be considered as a great threat to water security under future climate, which consequently lead to reduced food security. Hence, new insights for achieving a higher level of food and water security under global warming need to be developed, enabling policy makers to implement new effective adaptation solutions. In this regard, some new solutions has been quantitatively analyzed in the following, which has been rarely considered in the previous researches.

\section{Scenario assessment}

After calibrating and validating the DSSAT model, this model together with the simulated climate data over the selected future period (i.e., early $21^{\text {th }}$ century (2011-2040), mid $21^{\text {th }}$ century (2041-2070), and late $21^{\text {th }}$ century (2071-2100)), was applied to quantitatively analyze the influence of selected adaptation scenarios on alleviating the negative consequences of global warming on water and food security. In this regard, we selected a wide range of management scenarios including, planting dates, irrigation water depths, and irrigation intervals, which are discussed in the following sections.

\section{Adjusting irrigation water depth}

Adopting the water-saving irrigation strategies may be of priority when a decreasing trend in blue water resources is observed in a highly water-stressed region. Being widely used by numerous 
researchers (Talebnejad and Sepaskhah 2014; Abd El-Halim and Abd El-Razek 2014; Karandish and Šimůnek 2017). Deficit irrigation (DI) may be considered as an effective adaptation solution under unavoidable global warming. Hence, we analyzed the probable consequences of applying DI at two levels of $55 \%\left(\mathrm{Dl}_{55}, 45 \%\right.$ less water than full) and $75 \%\left(\mathrm{Dl}_{75}, 25 \%\right.$ less water than full), for maize cropping in the study area, to see if the negative consequences of global warming may be compensated by reducing applied irrigation water.

The results of a quantitative analysis indicate that compared to the given results for FI treatment over the 2041-2070 period, a 7.9-42.8\% reduction in maize grain yield is expected when adopting $\mathrm{DI}_{75}$ under the elevated $\mathrm{CO}_{2}$, with the lower and the upper limits under $\mathrm{B} 1$ and A1B SRER scenarios, respectively (Table 3 ). Besides, $40.8-42.8 \%$ lower yield may be expected as well, when crops are exposed to $\mathrm{DI}_{55}$ over mid $21^{\text {th }}$ century. Despite of a general reduction in maize grain yield under water-saving irrigation strategies, climate change projections show more negative consequences over the 2071-2100 period. Our finding of reduced crop yield under DI has been supported by other researchers (Ma et al. 2017; Karandish and Šimůnek 2017; Pang et al. 2018).

Compared to the FI treatment and over the period 2011-2100, crop water requirement, which is a highlighted part of the hydrological models, is projected to be decreased by $2.5-4.98 \%$, when applying $\mathrm{DI}_{75}$, and is projected to be decreased by $14.4-18.4 \%$, when applying $\mathrm{DI}_{55}$ (Table 3 ). Regardless of the time period, the highest decrease is generally observed under A2 scenario, while the B1 scenario mainly expose the lowest decrease.

While crop water requirement and crop yield are the most proper indices, respectively, for watersaving and for economic analysis, they would not be enough for implementing the long-term planning under global warming, if they are considered individually. Hence, we calculated WUE to evaluate the suitability of the considered water-saving treatments. Over the mid $21^{\text {th }}$ century, applying $\mathrm{Dl}_{75}$ may result in a considerable reduction in WUEs by $4.24 \%$ (under B1 SRER scenario), up to $5.53 \%$ (under A1B SRER scenario), compared to fully irrigating crops. The same was for the other periods, however, climate change had the most severe consequences over the 2071-2100 period. Such reduction of considerably higher, when applying $\mathrm{Dl}_{75}$, which is a sign of serious food and water loss over the future periods.

Given results in this section may indicate that applying $\mathrm{Dl}_{75}$ is a proper adaptation solution under global warming, since it results in a slight reduction in maize grain yield, together with a considerable reduction in crop water requirement. Consequently, WUE, which is known as a comprehensive index of both water consumption and economic incomes, will be held at a favorable level under this treatment in the warmer future, which emphasize on higher level of foodwater security under global warming.

\section{Adjusting planting date}

Under a warmer climate, a change in the planting date may be considered as a suitable pathway for improving crop water productivity. Local farmers also moved to the new cropping calendars with gradual air temperature change over the past decades (Thoai et al. 2018). Hence, we quantified the probable consequences of adopting different planting dates on crop and water productivities under global warming. In this regard, we implement three type of cropping date: (i) normal cropping date, which is the date conventionally adopted by the local farmers in the study area, (ii) early planting dates, (iii) and late planting dates. In the study area, maize is normally cultivated in May 20, which is the $140^{\text {th }}$ day of the Julian year. Hence, we selected this data as a normal planning data, and selected the $120^{\text {th }}$ and $130^{\text {th }}$ Julian day as the early planting dates, and the $150^{\text {th }}$ and $160^{\text {th }}$ Julian day as late planting dates. Analyzing further consequences of the adjusted cropping dates was done for all considered irrigation water depths, including $\mathrm{FI}_{1} \mathrm{Dl}_{75}$ and $\mathrm{DI}_{55}$.

Over the period $2041-2070$ (i.e., mid $21^{\text {th }}$ century), early planting under FI treatment may result in a $0.3-5.2 \%$ increase in crop yield, and a general increase of $1.8-5.6 \%$ in ETc (Figure 2). Such projections resulted in a $0.4-4.9 \%$ reduction in WUEs, with the lowest and the highest reduction under B1 and A2 SRES scenarios, respectively. These results imply that the negative consequences of 


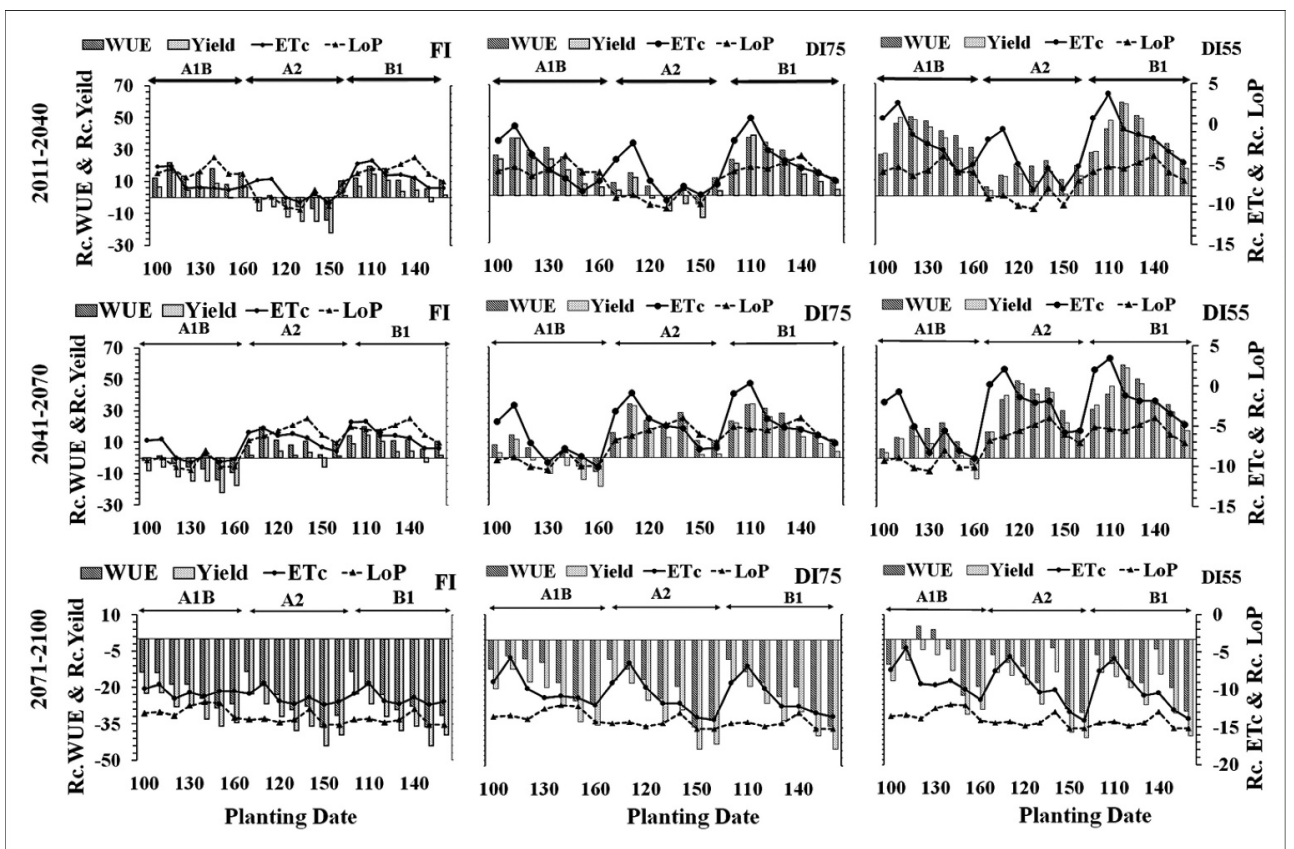

Figure 2. Relative change in crop yield (Rc.Y), crop water requirement (Rc.ETc), crop water use efficiency (Rc.WUE), and the length of cropping cycle (Rc.CS) under early and late planting compared to the normal planting date and based on the average results of the 15 GCMs for each scenario in the future period.

global warming on ETc is neutralized by its positive effect on crop yield. Our analysis in this timeperiod also reveals that late planting under FI treatment may improve crop yield by $0.7-4.9 \%$, and reduce crop water requirement by $3.5-6.6 \%$. While a similar result was observed for the early $21^{\text {th }}$ century, the reported results for 2071-2100 well indicates that global warming projections shows both positive and negative change in crop yield, ETc and crop WUE when adopting late planting under full irrigation. Such results may indicate that cropping date may be critically selected in a way that the negative consequences of increased air temperature on crop growth and crop water requirement is compensated by the positive influence of the elevated $\mathrm{CO}_{2}$ on crop yield.

The reported results in Figure 2 well reveal that selecting a proper cropping date under global warming highly depends on the irrigation strategy as well. Over the period 2041-2070, the 2.5-$14.6 \%$ reduction in WUE under early planting in the $\mathrm{Dl}_{75}$ treatment may be mainly associated with the $6.3-12.2 \%$ reduction in crop yield, rather than a slight increase of $1.9-3.1 \%$ in ETc. Conversely, late planting almost resulted in improved WUE under $\mathrm{DI}_{75}$, accounted for $5.1-16.5 \%$ over the 2041-2070 period. A relatively higher improvement in WUE under $\mathrm{DI}_{75}$ compared to the corresponding values under FI may indicate the higher importance of adjusting the cropping calendar when crops are under water stress.

Despite the different results given for the different SRES scenarios and future time-periods, climate change projections do not follow a uniform pattern when analyzing the influence of adjusting planting date on WUEs under $\mathrm{DI}_{55}$. In fact, the normal planting date may be considered as the best choice for this treatment, which emphasizes the key role of the severity of water stress when selecting the optimum cropping calendars.

\section{Adjusting irrigation intervals}

Irrigation interval (IIN) is a key factor that controls crop water requirement through affecting soil evaporation and soil water content (Moura et al. 2017). When crops are irrigated more frequently, 
higher evaporation and root water uptake will happen (Allen et al. 1998). Conversely, less frequent irrigation may reduce evapotranspiration through reducing soil evaporation, or reducing root water uptake under limited soil water content. Hence, we tried to find out the best IIN under global warming, under which the best WUE is obtained. In addition to the normal IIN in the study area (i,e., every other days, IIN =2), we also analyzed the possible consequences when IIN is set to 1, 3,4 and 5 days. The relative change in crop yield, ETc and WUE under new supposed IIN compared to the normal one (i.e., IIN = 2) is summarized in Figure 3. Both crop yield and ETc showed significant sensitivity to any change in IIN. Regardless of the treatments, less frequent irrigation may result in higher WUEs, mainly due to a significant reduction in ETc. Such improvement is more significant under conditions of water stress. Changing IIN from 2 (i.e., the normal IIN) to 5 (i.e., the optimum IIN), may improve WUE by $0.57-5.02 \%$ under $\mathrm{Fl}$, by $11.2-21.7 \%$ under $\mathrm{DI}_{75}$, and by $34.3-42.5 \%$ under $\mathrm{DI}_{55}$.

\section{A comparison among adaptation solutions}

In order to introduce the best adaptation scenario for achieving the highest food-water security under global warming, we determined the highest WUE for each adaptation scenario based on the ensemble average of $15 \mathrm{GCMs}$ and three SRER scenarios for each time period. Table 4 shows that with a slight reduction of $2.3-5.5 \%$ in WUE, deficit irrigation with $25 \%$ less irrigation water guarantees higher food-water security over the period 2011-2100, due to less irrigation water use and only a slight reduction in food production. In fact, the saved water may be further used for developing the irrigated lands, or for industrial development. However, deficit irrigation with $45 \%$ reduction in irrigation water depth may intensify the negative consequences of climate change, since its application may result in a $21.8-26.6 \%$ reduction in WUE compared to the FI treatment, and a $20-22.3 \%$ reduction in WUE compared to $\mathrm{DI}_{75}$ treatment (i.e., under normal cropping data and IIN).

Table 4 also indicates the positive effects of adjusting cropping calendar under global warming. The WUEs under the $\mathrm{Dl}_{75}$ treatment may be improved by $6.5-20.7 \%$ when shifting cropping date from $140^{\text {th }}$ Julian day to $160^{\text {th }}$ Julian day. Nevertheless, adjusting IIN may be a better solution for achieving higher levels of food-water security under global warming. Changing IIN from 2 days (the

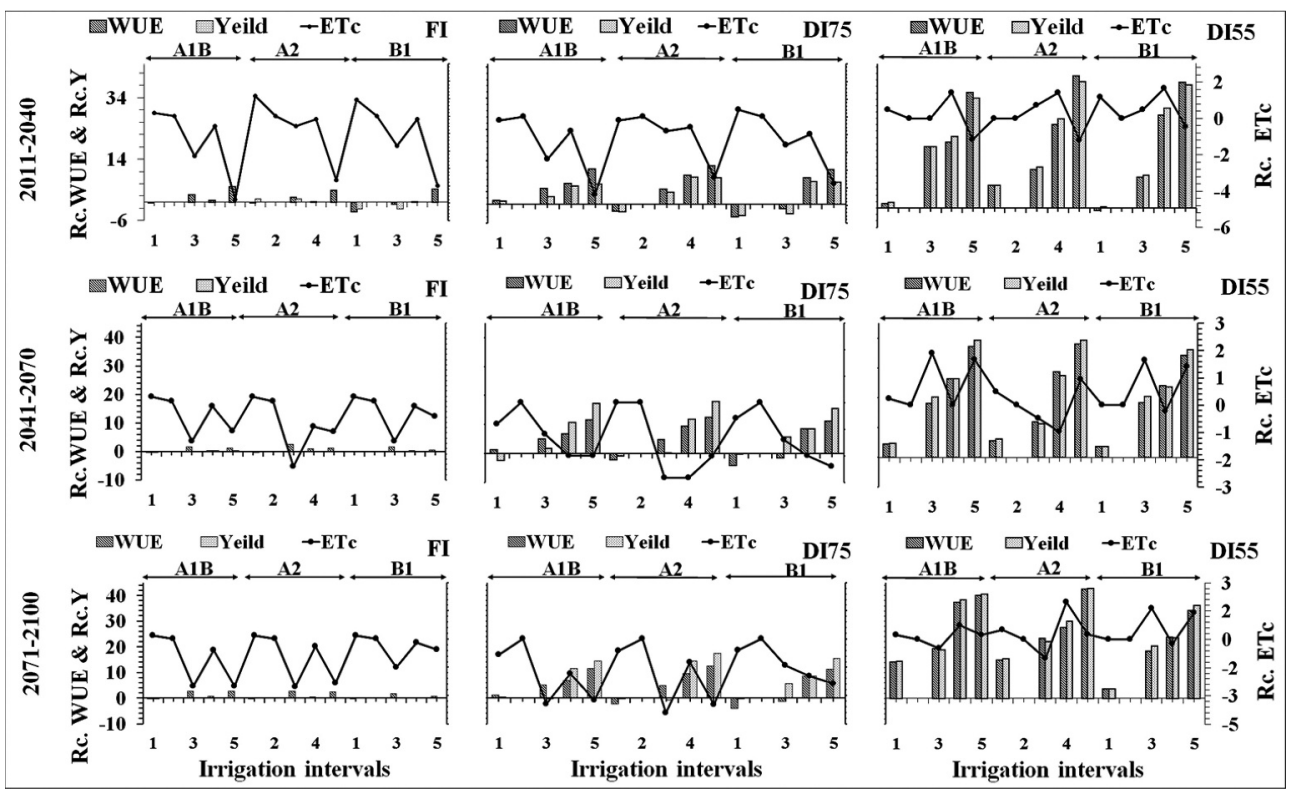

Figure 3. Relative change in crop yield (Rc.Y), crop water requirement (Rc.ETc) and crop water use efficiency (Rc.WUE) under new supposed irrigation intervals (IIN) compared to the normal one (IIN = 2) based on the average results of the $15 \mathrm{GCMs}$ for each scenario in the future period. 
Table 4. Optimum planting data and irrigation interval for the full and deficit irrigation treatments regarding WUEs calculated based on ensemble average of the 15 GCMs and three SRES scenarios for the base and future periods.

\begin{tabular}{|c|c|c|c|c|c|c|c|c|c|}
\hline \multirow[b]{2}{*}{ Time period } & \multirow[b]{2}{*}{ Treatment } & \multicolumn{4}{|c|}{ Solution: adjusting cropping calendars } & \multicolumn{4}{|c|}{ Solution: adjusting irrigation interval } \\
\hline & & $\begin{array}{c}\text { Normal } \\
\text { date }\end{array}$ & WUE $_{n d}{ }^{*}$ & $\begin{array}{l}\text { Best } \\
\text { date }\end{array}$ & $W_{U E} E_{b d}$ & $\begin{array}{l}\text { Normal } \\
\text { interval }\end{array}$ & WUE $_{\mathrm{ni}}$ & $\begin{array}{c}\text { Best } \\
\text { interval }\end{array}$ & WUE $_{\mathrm{bi}}$ \\
\hline \multirow{3}{*}{$\begin{array}{l}\text { Base period } \\
\quad(1980-2010)\end{array}$} & $\mathrm{FI}$ & 140 & 11.9 & 160 & 13.4 & 2 & 11.9 & 3 & 12.1 \\
\hline & DI75 & 140 & 10.4 & 160 & 13.0 & 2 & 10.4 & 5 & 12.8 \\
\hline & DI55 & 140 & 7.1 & 160 & 8.7 & 2 & 7.1 & 5 & 9.8 \\
\hline \multirow[t]{3}{*}{$2011-2040$} & $\mathrm{FI}$ & 140 & 14.2 & 160 & 16.7 & 2 & 14.2 & 5 & 14.8 \\
\hline & DI75 & 140 & 13.6 & 160 & 16.4 & 2 & 13.6 & 5 & 15.2 \\
\hline & DI55 & 140 & 9.8 & 160 & 11.3 & 2 & 9.8 & 5 & 13.6 \\
\hline \multirow[t]{3}{*}{ 2041-2070 } & $\mathrm{FI}$ & 140 & 11.5 & 160 & 12.8 & 2 & 11.5 & 3 & 11.8 \\
\hline & DI75 & 140 & 10.9 & 160 & 12.2 & 2 & 10.9 & 5 & 13.0 \\
\hline & DI55 & 140 & 8.1 & 160 & 8.4 & 2 & 8.1 & 5 & 11.1 \\
\hline \multirow[t]{3}{*}{$2071-2100$} & $\mathrm{FI}$ & 140 & 9.7 & 100 & 10.8 & 2 & 9.7 & 3 & 9.9 \\
\hline & DI75 & 140 & 9.2 & 160 & 9.8 & 2 & 9.2 & 5 & 11.0 \\
\hline & DI55 & 140 & 6.8 & 140 & 6.0 & 2 & 6.8 & 5 & 9.4 \\
\hline
\end{tabular}

*WUE: Water Use Efficiency $\left(\mathrm{Kg} \mathrm{ha}^{-1} \mathrm{~mm}^{-1}\right), W_{\mathrm{nd}}$ and WUE $\mathrm{bd}_{\mathrm{b}}$ are WUEs under normal and optimum cropping date, respectively. In addition, $W_{U E}$ and $W U E_{b i}$ are WUE under normal and optimum irrigation intervals.

normal IIN) to 5 days (the optimum IIN) may result in an $11.5-19.7 \%$ increase in WUEs under $\mathrm{Dl}_{75}$ over the period 2011-2100.

Adjusting the cropping calendar and/or IIN is expected to be a favorable adaptation solutions under the $\mathrm{FI}$ and $\mathrm{DI}_{55}$ treatments as well, since such adaptations may result is a $1.7-25 \%$ increase in WUE, which is an indication of higher crop per drop under future climate. These results indicate that implementing such strategies may overcome food-water insecurity in the future despite the significant negative consequences of global warming.

\section{Conclusion}

A field-modeling approach was used to investigate the probable consequences of global warming on sustainable maize production in Northern Iran, and to investigate the favorable adaptation solutions for achieving higher level of security both for food and water in the future. Following a twoyear field research, the DSSAT4.7 - CERES maize model was calibrated, validated, and applied together with the LARS-WG 5.5 to evaluate the global warming consequences over the 2011-2040 (early-), 2041-2070 (mid-), and 2071-2100 (late-) $21^{\text {th }}$ centuries. The main findings of this research are as follows:

- Sustainable maize production is threatened by global warming in the study area, since a 1.29-$37.4 \%$ reduction in maize yield is expected to occur under current cultivation conditions.

- Food-water insecurity may be intensified following a 5.1-27.2\% reduction in WUEs during the $21^{\text {th }}$ century (less crop per drop), when crops are fully irrigated.

- While deficit irrigation (DI) is an effective pathway for overcoming water insecurity in the future, the severity of the exposed water stress to crops needs to be adjusted when food security is also considered. DI with $25 \%$ less irrigation water than full irrigation is the optimum watersaving irrigation strategy, under which a slight reduction in crop yield is expected, while a $25 \%$ irrigation water will be saved in the future periods.

- While early planting causes a noteworthy crop and water loss, a 10-20 days delay in planting date over the period 2011-2100 almost resulted in improved WUE, especially under $\mathrm{DI}_{75}$.

- Less frequent irrigation over the 2011-2100 period results in higher crop per drop, through a substantial reduction in crop water requirement and a slight reduction in crop yield. Adopting such solution may result in higher increase in WUE when applying $\mathrm{DI}_{75}$. 
- Regarding the WUE index, the highest level of food-water security through maize cultivation is obtained when crops are cultivated by a 10-20 days delay, and are exposed to DI with $25 \%$ less irrigation water, and are irrigated with a five-day interval.

- As an overall conclusion, the given results in this study demonstrate that the negative consequences of global warming may be compensated if new and effective water and field managements are adopted in the future. Hence, food-water security under conditions of climate change will benefit from future similar researches for different crops, especially for the other crops in cereals group, which are the main source of human food diet.

\section{Disclosure statement}

No potential conflict of interest was reported by the authors.

\section{ORCID}

Mahdi Kalanaki (iD http://orcid.org/0000-0002-0271-204X

Henk Ritzema (iD http://orcid.org/0000-0003-2486-9926

Moosa Kalanaki (iD) http://orcid.org/0000-0002-8662-6658

\section{References}

Aeha AE-H, Abd El-Razek U. 2014. Effect of different irrigation intervals on water saving, water productivity and grain yield of maize (Zea mays L.) under the double ridge-furrow planting technique. Arch Agron Soil Sci. 60(5):587-596. doi:10.1080/03650340.2013.825900.

Allen RG, Pereira LS, Raes D, Smith M 1998. Crop evapotranspiration-Guidelines for computing crop water requirements-FAO Irrigation and drainage paper 56. Rome. http://www.kimberly.uidaho.edu/water/fao56/fao56.pdf

Atlin GN, Cairns JE, Das B. 2017. Rapid breeding and varietal replacement are critical to adaptation of cropping systems in the developing world to climate change. Glob Food Sec. 12:31-37. doi:10.1016/j.gfs.2017.01.008.

Attia A, Rajan N, Xue Q, Nair S, Ibrahim A, Hays D. 2016. Application of DSSAT-CERES-Wheat model to simulate winter wheat response to irrigation management in the Texas High Plains. Agric Water Manag. 165:50-60. doi:10.1016/j. agwat.2015.11.002.

Bastiaanssen WGM, Steduto P. 2017. The water productivity score (WPS) at global and regional level: methodology and first results from remote sensing measurements of wheat, rice and maize. Sci Total Environ. 575:595-611. doi:10.1016/j.scitotenv.2016.09.032.

Brisson N, Gary C, Justes E, Roche R, Mary B, Ripoche D, Zimmer D, Sierra J, Bertuzzi P, Burger P, et al. 2003. An overview of the crop model STICS. Eur J Agron. 18(3-4):309-332. doi:10.1016/S1161-0301(02)00110-7

Chisanga CB, Phiri E, Shepande C, Sichingabula H. 2015. Evaluating CERES-maize model using planting dates and nitrogen fertilizer in Zambia. J Agric Sci. 7(3):79-97.

da Silva JR, Patterson AE, Rodrigues WP, Campostrini E, Griffin KL. 2017. Photosynthetic acclimation to elevated CO2 combined with partial rootzone drying results in improved water use efficiency, drought tolerance and leaf carbon balance of grapevines (Vitis labrusca). Environ Exp Bot. 134:82-95. doi:10.1016/j.envexpbot.2016.11.007.

Darzi-Naftchali A, Karandish F. 2019. Adapting rice production to climate change for sustainable blue water consumption: an economic and virtual water analysis. Theor Appl Climatol. 135(1-2):1-2. doi:10.1007/s00704-017-2355-7.

Ding DY, Feng H, Zhao Y, He JQ, Zou YF, Jin J. 2016. Modifying winter wheat sowing date as an adaptation to climate change on the loess plateau. Agron J. 108(1):53-63. doi:10.2134/agronj15.0262.

FAO. 2018. World food and agriculture - statistical pocketbook 2018. Rome. [place unknown]. [accessed 2020 Jul 11 ]. http://www.wipo.int/amc/en/mediation/rules.

Fraga H, García de Cortázar Atauri I, Santos JA. 2018. Viticultural irrigation demands under climate change scenarios in Portugal. Agric Water Manag. 196:66-74. doi:10.1016/j.agwat.2017.10.023.

Gilanipour J, Gholizadeh B 2016. Prediction of rice water requirement using FAO-CROPWAT model in North Iran under future climate change. (October):1-9.

Guoju X, Fengju Z, Zhengji Q, Yubi Y. 2013. Impact of climate change on water use efficiency by wheat, potato and corn in semiarid areas of China. Agric Ecosyst Environ. 181:108-114. doi:10.1016/j.agee.2013.09.019.

Hatfield JL, Dold C. 2019. Water-use efficiency: advances and challenges in a changing climate. Front Plant Sci. $10: 103$. doi:10.3389/fpls.2019.00103. 
Hoogenboom G, Porter CH, Boote KJ, Shelia V, Wilkens PW, Singh U, White JW, Asseng S, Lizaso Jl, Moreno LP, et al. The DSSAT crop modeling ecosystem. Cambridge (United Kingdom): Burleigh Dodds Science Publishing. Boote K, editor. 2019.

Huang S, Lv L, Zhu J, Li Y, Tao H, Wang P. 2018. Extending growing period is limited to offsetting negative effects of climate changes on maize yield in the North China Plain. F Crop Res. 215:66-73. doi:10.1016/j.fcr.2017.09.015.

IPCC. 2007. Climate Change 2007: synthesis Report. Contribution of Working Groups I, II and III to the Fourth Assessment Report of the Intergovernmental Panel on Climate Change [Core Writing Team, Pachauri RK and Reisinger A. (eds.)]. Geneva (Switzerland).

Jeong $\mathrm{H}$, Jang T, Seong C, Park S. 2014. Assessing nitrogen fertilizer rates and split applications using the DSSAT model for rice irrigated with urban wastewater. Agric Water Manag. 141:1-9. doi:10.1016/j.agwat.2014.04.009.

Jepsen SM, Harmon TC, Ficklin DL, Molotch NP, Guan B. 2018. Evapotranspiration sensitivity to air temperature across a snow-influenced watershed: space-for-time substitution versus integrated watershed modeling. J Hydrol. 556:645-659. doi:10.1016/j.jhydrol.2017.11.042.

Jiang Y, Zhang L, Zhang B, He C, Jin X, Bai X. 2016. Modeling irrigation management for water conservation by DSSAT-maize model in arid northwestern China. Agric Water Manag. 177:37-45. doi:10.1016/j.agwat.2016.06.014.

Johnston RZ, Sandefur HN, Bandekar P, Matlock MD, Haggard BE, Thoma G. 2015. Predicting changes in yield and water use in the production of corn in the United States under climate change scenarios. Ecol Eng. 82:555-565. doi:10.1016/j.ecoleng.2015.05.021.

Kalanaki M, Ritzema H, Bamshad R, Jones E, Fazilatnia M. 2020. Application of bio-desalinization for reclamation of salt-affected soil under composted cow manure and deficit irrigation with saline water. Paddy Water Environ. 18 (2):469-479. doi:10.1007/s10333-020-00795-7.

Kang S, Hao X, Du T, Tong L, Su X, Lu H, Li X, Huo Z, Li S, Ding R. 2017. Improving agricultural water productivity to ensure food security in China under changing environment: from research to practice. Agric Water Manag. 179:5-17. doi:10.1016/j.agwat.2016.05.007.

Karandish F, Hoekstra AY. 2017. Informing national food and water security policy through water footprint assessment: the Case of Iran. Water (Switzerland). 9:11.

Karandish F, Kalanaki M, Saberali SF. 2017a. Projected impacts of global warming on cropping calendar and water requirement of maize in a humid climate. Arch Agron Soil Sci. 63(1):1-13. doi:10.1080/03650340.2016.1177176.

Karandish F, Mousavi SS, Tabari H. 2017b. Climate change impact on precipitation and cardinal temperatures in different climatic zones in Iran: analyzing the probable effects on cereal water-use efficiency. Stoch Environ Res Risk Assess. 31 (8):2121-2146. doi:10.1007/s00477-016-1355-y.

Karandish F, Šimůnek J. 2017. Two-dimensional modeling of nitrogen and water dynamics for various N-managed water-saving irrigation strategies using HYDRUS. Agric Water Manag. 193:174-190. doi:10.1016/j.agwat.2017.07.023.

Karimi V, Karami E, Keshavarz M. 2018. Climate change and agriculture: impacts and adaptive responses in Iran. J Integr Agric [Internet]. 17(1):1-15. doi:10.1016/S2095-3119(17)61794-5.

Kassie BT, Asseng S, Rotter RP, Hengsdijk H, Ruane AC, Van Ittersum MK. 2015. Exploring climate change impacts and adaptation options for maize production in the Central Rift Valley of Ethiopia using different climate change scenarios and crop models. Clim Change. 129(1-2):145-158. doi:10.1007/s10584-014-1322-x.

Lana MA, Eulenstein F, Schlindwein S, Guevara E, Meira S, Wurbs A, Sieber S, Svoboda N, Bonatti M. 2016. Regionalization of climate scenarios impacts on maize production and the role of cultivar and planting date as an adaptation strategy. Reg Environ Chang. 16(5):1319-1331. doi:10.1007/s10113-015-0860-8.

Lin T, Xie Y, Liu G, Chen D, Duan X. 2008. Impact of climate change on crop yields in Heilongjiang Province. J Nat Resour. 23(2):307-318.

Lizaso Jl, Ruiz-Ramos M, Rodríguez L, Gabaldon-Leal C, Oliveira JA, Lorite IJ, Sánchez D, García E, Rodríguez A. 2018. Impact of high temperatures in maize: phenology and yield components. F Crop Res. 216:129-140. June 2017. doi:10.1016/j.fcr.2017.11.013.

Ma L, Ahuja LR, Islam A, Trout TJ, Saseendran SA, Malone RW. 2017. Modeling yield and biomass responses of maize cultivars to climate change under full and deficit irrigation. Agric Water Manag. 180:88-98. doi:10.1016/j. agwat.2016.11.007.

McCown RL, Hammer GL, Hargreaves JNG, Holzworth DP, Freebairn DM. 1996. APSIM: a novel software system for model development, model testing and simulation in agricultural systems research. Agric Syst [Internet]. 50(3): $255-271$. [accessed 2020. Jul 11 https://yncenter.sites.yale.edu/sites/default/files/mao_yangyang_mar_2015.pdf

Moura EG, Macedo VRA, Sena VGL, Campos LS, Aguiar ACF. 2017. Soil physical changes and maize growth in a structurally fragile tropical soil due to mulching and duration between irrigation intervals. Soil Use Manag. 33 (4):631-638. doi:10.1111/sum.12382.

Muluneh A, Stroosnijder L, Keesstra S, Biazin B. 2017. Adapting to climate change for food security in the Rift Valley dry lands of Ethiopia: supplemental irrigation, plant density and sowing date. J Agric Sci. 155(5):703-724. doi:10.1017/ S0021859616000897.

Musinguzi P, Ebanyat P, Tenywa JS, Mwanjalolo M, Basamba TA, Tenywa MM, Porter C. 2014. Using DSSAT-CENTURY model to simulate soil organic carbon dynamics under a low-input maize cropping system. J Agric Sci. 6(5):120-131.

Nosrati K. 2011. The effects of hydrological drought on water quality. IAHS-AISH Publ. 348(July):51-56. 
Pang B, Zhang K, Kisekka I, Bean S, Zhang M, Wang D. 2018. Evaluating effects of deficit irrigation strategies on grain sorghum attributes and biofuel production. J Cereal Sci. 79:13-20. doi:10.1016/j.jcs.2017.09.002.

Paredes P, de Melo-abreu JP, Alves I, Pereira LS. 2014. Assessing the performance of the FAO AquaCrop model to estimate maize yields and water use under full and deficit irrigation with focus on model parameterization. Agric Water Manag. 144:81-97. doi:10.1016/j.agwat.2014.06.002.

Rad LK, Mohammadi H, Teyfoori V. 2015. Impacts of Climate Change on Droughts in Gilan Province, Iran. Ecol Balk. 7 (1):29-38.

Rahimi J, Malekian A, Khalili A. 2019. Climate change impacts in Iran: assessing our current knowledge. Theor Appl Climatol. 135(1-2):545-564. doi:10.1007/s00704-018-2395-7.

Reddy KS, Kumar M, Maruthi V, Umesha B, Vijayalaxmi, Nageswar RCVK. 2014. Climate change analysis in southern Telangana region, Andhra Pradesh using LARS-WG model. Curr Sci. 107(1):54-62.

Romero-Trigueros C, Parra M, Bayona JM, Nortes PA, Alarcón JJ, Nicolás E. 2017. Effect of deficit irrigation and reclaimed water on yield and quality of grapefruits at harvest and postharvest. LWT - Food Sci Technol. 85:405-411. doi:10.1016/j.lwt.2017.05.001.

Saseendran SA, Ahuja LR, Ma L, Trout TJ. 2015. Modeling for best management of the effects of irrigation frequencies, initial water, and nitrogen on corn. In: Ahuja Lajpat R., Ma Liwang, Lascano RJ, editors. Pract Appl Agric Syst Model to Optim Use Ltd Water. Vol. 5. Madison, WI, USA: American Society of Agronomy and Soil Science Society of America; p. 25-52.

Semenov MA, Barrow EM. 2002. LARS-WG A stochastic weather generator for use in climate impact studies LARS-WG: stochastic weather generator contents. UK: Hertfordshire.

Soler CMT, Sentelhas PC, Hoogenboom G. 2007. Application of the CSM-CERES-Maize model for planting date evaluation and yield forecasting for maize grown off-season in a subtropical environment. Eur J Agron. 27(2-4):165-177. doi:10.1016/j.eja.2007.03.002.

Stockle CO, Martin SA, Campbell GS. 1994. CropSyst, a cropping systems simulation model: water/nitrogen budgets and crop yield. Agric Syst. 46(3):335-359. doi:10.1016/0308-521X(94)90006-2.

Talebnejad R, Sepaskhah AR. 2014. Effects of water-saving irrigation and groundwater depth on direct seeding rice growth, yield, and water use in a semi-arid region. Arch Agron Soil Sci. 60(1):15-31. doi:10.1080/ 03650340.2013.770598.

Thoai TQ, Rañola RF, Camacho LD, Simelton E. 2018. Determinants of farmers' adaptation to climate change in agricultural production in the central region of Vietnam. Land Use Policy. 70:224-231. doi:10.1016/j. landusepol.2017.10.023.

van Diepen CA, Wolf J, van Keulen H, Rappoldt C. 1989. WOFOST: a simulation model of crop production. Soil Use Manag. 5(1):16-24. doi:10.1111/j.1475-2743.1989.tb00755.x.

van Laar HH, Goudriaan J, Van Keulen H. 1997. SUCROS97: simulation of crop growth for potential and water-limited production situations. Quant Approaches Syst Anal. 14(September):1-12.

Wang J, Liu X, Cheng K, Zhang X, Li L, Pan G. 2018. Winter wheat water requirement and utilization efficiency under simulated climate change conditions: A Penman-Monteith model evaluation. Agric Water Manag. 197:100-109. doi:10.1016/j.agwat.2017.11.015.

Wang J, Tong L, Kang S, Li F, Zhang X, Ding R, Du T, Li S. 2017. Flowering characteristics and yield of maize inbreds grown for hybrid seed production under deficit irrigation. Crop Sci. 57(4):2238-2250. doi:10.2135/cropsci2016.10.0868.

Williams JR, Jones CA, Kiniry JR, Spanel DA. 1989. EPIC crop growth model. Trans Am Soc Agric Eng. 32(2):497-511. doi:10.13031/2013.31032.

Yang C, Fraga H, Van IW, Santos JA. 2017. Assessment of irrigated maize yield response to climate change scenarios in Portugal. Agric Water Manag. 184:178-190. doi:10.1016/j.agwat.2017.02.004. 